\title{
LETTERS
}

\section{Doctors share responsibility for damaging discourse}

This is in response to an editorial by $\mathrm{Dr}$. Stanbrook. ${ }^{1}$ There is little question that the public discourse surrounding proposed tax reforms has been profoundly damaging to the reputation of physicians in Canada. To assign primary blame for this on the federal government is out of touch.

The overwrought response of physicians to proposed reforms has been more damaging to our professional reputation than the admittedly unhelpful rhetoric from the federal government. These proposals are a first step in reforming a tax system that systematically advantages the wealthiest $5 \%$, which includes physicians, and exacerbates income inequality - a substantial contributor to poor health outcomes. ${ }^{2}$ When the public views physicians as more concerned with protecting our financial privilege than health outcomes, they have every reason to question our integrity.
According to an analysis by MD Management, ${ }^{3}$ these changes will affect only a few physicians and in only a small way. Yet, physicians have gone so far as to threaten withdrawal of care, ${ }^{4,5}$ a reckless response that is shamefully reminiscent of the doctors' strike after the introduction of Medicare.

I think that Dr. Stanbrook's call for unity is an attempt to silence those of us who support, albeit with qualifications, these reforms. No, we are not tax cheats, but we are using a system that needs fixing. Instead of defending it, let's address the legitimate calls among physicians for basic protections including parental and sick leave, retirement planning and reasonable work hours, which should be the right of all.

\section{Kieran Conway MD}

Family physician, Touchwood Qu'Appelle Primary Care Collaborative,

Fort Qu'Appelle, Sask.

Cite as: CMAJ 2018 January 8;190:E21. doi: $10.1503 /$ cmaj. 733500

\section{References}

1. Stanbrook MB. Tax reform plays politics with doctors' reputations. CMAJ 2017;189:E1249.

2. National Research Council (US) Committee on Future Directions for Behavioral and Social Sciences Research at the National Institutes of Health. Singer $\mathrm{BH}$, Ryff CD, editors. New horizons in health: an integrative approach. Washington: National Academies Press; 2001. Available: www.ncbi.nlm.nih.gov/ books/NBK43780/ (accessed 2017 Oct. 2).

3. Maltinsky E. Tax planning using private corporations, what's next: a summary of finance announcements [blog]. Ottawa: MD Management; 2017. Available: https://mdm.ca/md-blogs/tax -planning-using-private-corporations-what-s-next -a-summary-of-finance-announcements (accessed 2017 Oct. 2).

4. Maritime doctors threaten to leave region over tax changes. CTV News Atlantic 2017 Sept. 30. Available: http://atlantic.ctvnews.ca/maritime -doctors-threaten-to-leave-region-over-tax-changes -1.3613943 (accessed 2017 Oct. 2).

5. Curry B. Morneau defends tax change that has doctors threatening to leave Canada. The Globe and Mail [Toronto] 2016 Dec. 6. Available: https://beta.theglobeandmail.com/news/politics /morneau-defends-tax-change-that-has-doctors -threatening-to-leave-canada/article33225417/? ref=http://www.theglobeandmail.com\& (accessed 2017 Oct. 2).

Competing interests: Kieran Conway is an incorporated physician. 